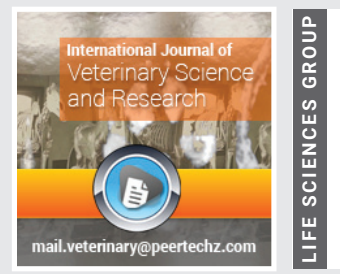

\title{
Effect of follicular ablation and gonadotropin priming on the recovery and quality of oocytes
} in Boran cows

\author{
Tilaye Demissie ${ }^{1 \star}$, Tefera Yilma ${ }^{1}$, Tamrat Degefa ${ }^{2}$, Gemechu \\ Wirtu $^{3}$ and Alemayehu Lemma ${ }^{1}$ \\ ${ }^{1} \mathrm{PhD}$, Associate Professor, Clinical Studies, Addis Ababa University, College of Veterinary Medicine \& \\ Agriculture, Ethiopia \\ ${ }^{2}$ Ethiopian Institute of Agricultural Research, Debre-Zeit Agricultural Research Center, Ethiopia \\ ${ }^{3}$ Tuskegee University, College of Veterinary Medicine, Alabama, USA
}

Received: 16 September, 2021

Accepted: 21 October, 2021

Published: 22 October, 2021

*Corresponding author: Tilaye Demissie, $\mathrm{PhD}$, Associate Professor, Clinical Studies, Addis Ababa University, College of Veterinary Medicine \& Agriculture, Ethiopia, Tel: +251-913-299098; Fax:+251-11-4339933, E-mail: tilaye.demissie@aau.edu.et

\section{ORCID: https://orcid.org/0000-0002-4758-5558}

Keywords: Boran; Bovine-oocyte; Cumulus oocyte complex; Coasting time; Follicle stimulation hormone

Copyright: (C) 2021 Demissie T, et al. This is an open-access article distributed under the terms of the Creative Commons Attribution License, which permits unrestricted use, distribution, and reproduction in any medium, provided the original author and source are credited.

https://www.peertechzpublications.com

\section{Check for updates}

\begin{abstract}
Genetic differences have been suggested as a possible cause for variation in responses to exogenous hormones. Here we evaluated the effect of follicle ablation, exogenous FSH and coasting time prior to ovum pick-up (OPU) on the number of follicles suitable for aspiration, oocyte quality, and cleavage rate in Ethiopian Boran

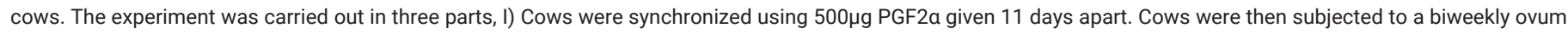
pickup session before ovulation $(n=5)$ or starting Day 7 after ovulation $(n=4)$ for three weeks. II) Cows were similarly synchronized and all visible follicles were ablated on the first days of overt estrus which were then further grouped into cows that received a divided dose of 350IU FSH ( $n=5$ ) or 175IU FSH ( $n=5$ ) over three days. In both groups OPU was carried out weekly starting $48 \mathrm{~h}$ after the last FSH for six weeks. III) A similar protocol as in part II was carried out but coasting period was increased to $72 \mathrm{hrs}$ for cows that received $350 \mathrm{IU}$ FSH as divided dose $(n=5)$ and $48 \mathrm{hrs}$ coasting period for single $350 \mathrm{OU}$ FSH dose ( $n=5)$. The covariates of follicles and oocyte were not affected $(P>0.05)$ by corpus luteum presence at OPU. The mean number of medium $(7.36 \pm 0.57)$ and large $(8.28 \pm 0.96)$ follicles were significantly higher $(P<0.05)$ in group that received divided 350IU FSH. Similarly, the mean number of Grade-1 (4.19 \pm 0.24$)$ and Grade-2 (4.32 \pm .27$)$ COC, maturation rate $(70.41 \%)$ and cleavage rate $(47.5 \%)$ were significantly higher $(\mathrm{P}<0.05)$ in group that received $350 \mathrm{OU}$ FSH. COC quality was significantly $(\mathrm{P}<0.05)$ influenced by costing period. However, both maturation and cleavage rates were not affected by the coasting period. This study demonstrated that follicular ablation and treatment with FSH improves follicular population and oocyte recovery rate in Boran cows.
\end{abstract}

\section{Introduction}

Boran cattle are the most suitable types of cattle breed for arid and semi-arid regions of East Africa including in Ethiopia due to their adaptive characteristics like tolerance to heat, resistance to diseases, and ability to utilize low quality forage and relatively better production performance $[1,2]$. The large majorities of crossbreeding in Ethiopia use crossing of Boran with Holstein. Genetic differences have been suggested as a possible cause for variation in responses to exogenous hormones. Moreover, different studies indicated that Bos taurus and Bos indicus breed have responded differently to ovarian stimulation and follicular growth. Reis, et al. [3] indicate that synchronizing follicular wave emergence prior to OPU improves COC quality and blastocysts only in Brangus but not in Nelore (Bos indicus) cattle while Rodriguez, et al. [4] reported that follicular wave synchronization and superstimulation improved COC quality and blastocyst rate in both Brangus and Angus cattle. The beneficial effect of gonadotrophins given prior to OPU and similarly the dose of Follicle Stimulating Hormone (FSH) used for ovarian stimulation have not been well studied in Bos indicus. In previous works, Mentigens, et al. [5] used 40mg FSH; Chasombat, et al. [6] used 100mg FSH, while Blondin, et al. [7] and Chaubal, et al. [8] each used 200mg FSH to stimulate the ovaries prior to OPU. The time of FSH withdrawal (coasting period) before OPU has effect on oocyte 
maturation and blastocyst development [7,9]. The work of Nivet, et al. [10] indicated that the optimal coasting time can range from 20 to $92 \mathrm{~h}$. We evaluated the effect of two FSH doses, FSH given either divided or at one time, and FSH priming at two coasting time on recovery and oocyte quality during OPU in Boran (Bos indicus) cows.

\section{Materials and methods}

\section{Study animals and experimental design}

The study animals were Boran cows with a mean ( \pm SEM) body condition score of $4.37 \pm 0.74$ (on a scale of $1-5$, $1=$ emaciated, $5=$ obese) and parity one. The study design was a crossover experimental design in which all cows would pass through each experiment after a rest of two inter-ovulatory interval (washout period) between successive experiments. The experimental groups were; experiment I (OPU without FSH priming in cows with and without CL), experiment II (OPU with follicular ablation and with different dose FSH priming and experiment III (OPU with follicular ablation, FSH priming and with different coasting period (Summarized in Table 1).

Briefly in experiment I, all cows were estrus synchronized by giving $500 \mu \mathrm{g}$ of PGF2 $\alpha$ (Synchromate ${ }^{\circledR}$, cloprostenol sodium, Warburg, Germany) at 11 days apart. After the second PGF2 $\alpha$, cows were visually followed for estrus signs and ovaries were scanned by ultrasound (Aloka SSD-500, Japan) twice a day. Upon estrus cows were randomly divided into two. In the first group, the first OPU was started when cows were in estrus but before ovulation (group CL negative, $n=5$ ) and OPU sessions were made twice a week for 3 consecutive weeks on each cow (total of 30 OPU sessions). In the second group, cows detected in estrus were confirmed for ovulation and CL development (ultrasound). At day 7 of ovulation (group CL positive, $\mathrm{n}=4$ ) the first OPU was started and OPU sessions were made twice a week for 3 consecutive weeks on each cow (total of $24 \mathrm{OPU}$ ). In each group, immediately before each OPU, follicles were quantified, size measured and classifies as small (3-4mm), medium (5-9mm) and large (>9mm) (Walters et al., 2002). In experiment II, cows were estrus synchronized as in experiment I and when cows were in estrus all visible follicles were ablated (FA) before ovulation and cows were randomly assigned into either Multiple FSH \& OPU48 $(n=5)$ or single FSH \& OPU48 $(n=5)$. In multiple FSH \& OPU48 group, on day 1 ( $24 \mathrm{~h}$ after FA), day 2 and day 3, respectively 175IU, 105IU, and 70 IU FSH (FOLLTROPIN ${ }^{\circledR}$, pFSH 141- 431 Vetoquinol CANADA) was given divided into morning and afternoon at $12 \mathrm{hr}$ (total dose $350 \mathrm{IU}$ ). On day 5 ( $48 \mathrm{hr}$ of the last FSH), the first OPU was performed and the subsequent OPUs were performed weekly in a similar protocol for six consecutive weeks. In single FSH group, FSH was given as a single dose (350IU, IM) to each cow $48 \mathrm{~h}$ prior to OPU. Six OPU were made per week per cow under a similar treatment. All cows were waited to pass through 2 estrus cycles before transferred to subsequent treatment. In experiment III, cows were divided into two groups as multiple $350 I U$ FSH \& OPU72 $(n=5)$ and multiple 175IU FSH \& OPU48 $(n=5)$. In multiple $350 I U$ FSH \& OPU72, the treatment is exactly same as multiple FSH \& OPU48 except all OPU sessions were performed at $72 \mathrm{hr}$ of the last FSH treatment $(72 \mathrm{hr}$ coasting period). In multiple 175IU FSH group, on day 1, day 2 and day 3 of follicles removal, respectively cows received 70IU, 70IU and 35IU FSH divided into morning and afternoon (total dose 175IU). All OPU sessions were performed at $48 \mathrm{hr}$ of the last FSH treatment weekly for six consecutive weeks.

\section{Follicular aspiration}

Before follicular aspiration both ovaries were scanned and follicles were counted and categorized in to small ( 3 to $4 \mathrm{~mm}$ ), medium ( 5 to $9 \mathrm{~mm}$ ) and large ( $>9 \mathrm{~mm})$ [11]. A transvaginal ultrasound (Aloka SSD-500, Japan) guided follicular aspiration was performed using a $55 \mathrm{~mm}$ long 18 -gauge stainless steel needle that was attached to a tubing and to the vacuum pump maintained at $80 \mathrm{~mm}$ of $\mathrm{Hg}$. Lidocaine $2 \%$ (JEIL pharma. co. LTD, Korea) was used as epidural anesthesia to facilitate the handling of the ovaries through the rectum. All follicles of $\geq 3 \mathrm{~mm}$ were aspirated into sterile $50 \mathrm{ml}$ conical tube that contains $15 \mathrm{ml}$ of TCM199 medium with HEPES buffer, 10\% fetal calf serum, penicillin $(10,000 \mathrm{IU} / \mathrm{ml})$, streptomycin $(50 \mu \mathrm{g} /$ $\mathrm{ml})$, and $25 \mu \mathrm{g} / \mathrm{ml}$ heparin.

\section{Oocyte collection and grading}

Oocytes were graded morphologically based on cumulus cells layers and homogeneity of cytoplasm as the following: Grade one (G1) three or more compact layers of cumulus oocyte cells and homogenous cytoplasm; Grade two (G2) two compact layers of cumulus oocyte cells and homogenous cytoplasm, Grade three (G3) irregular cumulus cells with one layers and dark agglomeration in the cytoplasm or absence of cumulus cell layers and irregular dark cytoplasm [12].

\section{Oocyte maturation, fertilization and culture}

Oocytes were washed 2-3 times in Tyrodes lactate (TLHEPES) oocyte wash medium. G1 and G2 oocytes were transferred into maturation medium prepared from TCM199, $10 \%$ fetal calf serum (FCS), $5 \mu \mathrm{g} / \mathrm{ml} \mathrm{bFSH}, 50 \mu \mathrm{g} / \mathrm{ml} \mathrm{bLH}$, penicillin $\mathrm{G}(50 \mathrm{IU} / \mathrm{ml}), 50 \mu \mathrm{g} / \mathrm{ml}$ streptomycine, $22 \mu \mathrm{g} / \mathrm{ml}$ sodium pyruvate [13]. Oocytes were incubated for $24 \mathrm{hrs}$ in 500 $\mu \mathrm{L}$ maturation medium covered with mineral oil. The incubator

Table 1: Tabular description of the experimental groups.

\begin{tabular}{|c|c|c|c|c|c|c|c|}
\hline Experiment & $\mathbf{N}$ & Group & Ablation & FSH dosage & OPU start & OPU frequency & Length of OPU \\
\hline \multirow{2}{*}{1} & \multirow{2}{*}{9} & $1 ; n=5$ & No & No & Before ovulation & $2 x / w k$ & 3 weeks \\
\hline & & $2 ; n=4$ & No & No & 7 days after & $2 x / w k$ & 3weeks \\
\hline \multirow{2}{*}{ II } & \multirow{2}{*}{10} & $1 ; n=5$ & All visible follicles & 350IU,divided & 48hrs after last FSH & $1 \mathrm{x} / \mathrm{wk}$ & 6 weeks \\
\hline & & $2 ; n=5$ & All visible follicles & 350IU, Single & 48hrs after last FSH & $1 \mathrm{x} / \mathrm{wk}$ & 6 weeks \\
\hline \multirow{2}{*}{ IIIt } & \multirow{2}{*}{10} & $1 ; n=5$ & All visible follicles & 350IU,divided & $72 \mathrm{hrs}$ after last FSH & $1 \mathrm{x} / \mathrm{wk}$ & 6 weeks \\
\hline & & $2 ; n=5$ & All visible follicles & 175IU,divided & 48hrs after last FSH & $1 \mathrm{x} / \mathrm{wk}$ & 6weeks \\
\hline
\end{tabular}

t results from group III were compared with the 350IU,dividedFSH and $48 \mathrm{hr}$ coasting period (from group II) and not with each other in group III.

Citation: Demissie T, Yilma T, Degefa T, Wirtu G, Lemma A (2021) Effect of follicular ablation and gonadotropin priming on the recovery and quality of oocytes in Boran cows. Int J Vet Sci Res 7(2): 138-143. DOI: https://dx.doi.org/10.17352/ijvsr.000093 
was maintained at 5\% $\mathrm{CO}_{2}$ in humidified air (90-95\% relative humidity) at $39.5^{\circ} \mathrm{C}$. After IVM, cumulus cell expansion and extrusion of the first polar body were recorded. The matured oocytes were washed twice in TALP-wash and transferred to TL-Fert (TALP-Fertilization) medium with $10 \mu \mathrm{g} / \mathrm{ml}$ heparin, $22 \mu \mathrm{g} / \mathrm{ml}$ sodium pyruvate, $50 \mu \mathrm{g} / \mathrm{ml}$ streptomycin, 10,000 IU penicillin, $6 \mathrm{mg} / \mathrm{ml}$ fatty acid free BSA . Semen straw was thawed, the sperms were washed in TL-HEPES (sperm wash) and separated using a percoll gradient. The final concentration of $1 \times 10^{6} / \mathrm{mL}$ sperm was used for fertilization. Oocytes and spermatozoa were co-incubated for $24 \mathrm{~h}$ at $39.5^{\circ} \mathrm{C}$ under $5 \% \mathrm{CO}_{2}$ and $95 \%$ humidity. Twenty four hours after fertilization, the presumptive zygotes were repeatedly pipetted in wash medium (TL-HEPES) and finally cultured in synthetic SOF medium under oil for $24 \mathrm{~h}$ at $39.5^{\circ} \mathrm{C}$ under $5 \% \mathrm{CO}_{2}$. Every twenty four hours the culture medium was changed and the morulae were physically evaluated based on number and compactness of cel and area of perivitelline space.

\section{Statistical analysis}

STATA (version 12) is used to analyze the data. The outcome or response variables were number of follicles of different categories, and number of oocytes recovered, oocyte quality, oocyte maturation and oocyte cleavage while treatment type was independent variable. Means $( \pm$ SE) were used to compare the response variables. To compare the difference between treatment mean either $t$-test or ANOVA was used based on the nature of data to be compared. Differences at $\mathrm{P}<0.05$ were taken as statistically significant.

\section{Results}

\section{Follicular and oocyte parameters in presence or absence of corpus luteum}

The details of number of follicles aspirated and oocyte yield are described in Table 2. The mean follicles aspirated and oocytes recovered was not affected $(\mathrm{P}>0.05)$ by CL presence at OPU. Similarly, there was no significant $(\mathrm{P}>0.05)$ difference in oocyte recovery rate, oocyte quality (grades), oocyte maturation and cleavage rate by CL presence on ovary at OPU (Table 3).

\section{Effect of FSH dose and FSH frequency on follicles and oocyte parameters}

The details of the mean follicles aspirated per OPU session are indicated in Table 4 . The mean $( \pm$ SE) number of medium and large follicles aspirated were significantly higher $(\mathrm{P}<0.05)$ in divided 350IU FSH than divided 175IU FSH doses. Comparatively, cows that received 175IU divided FSH dose had a significantly larger number of medium and large follicles than the control group (Table 4). All sizes of follicular population significantly increased $(\mathrm{P}<0.05)$ when $\mathrm{FSH}$ priming was given in divided dosage and when the coasting period was $48 \mathrm{hrs}$ than $72 \mathrm{~h}$.

In the 350IU FSH, the overall oocyte recovery rate was $63.76(593 / 930)$ and $61.24 \%(564 / 921)$, respectively, at $48 \mathrm{~h}$ $\mathrm{OPU}$, and at $72 \mathrm{~h}$ OPU and these recovery rates were significantly higher $(\mathrm{P}<0.05)$ than the $54.51 \%(278 / 510)$ recovery rate in the 350 IU FSH given as a single dose.
Table 2: Follicle number aspirated, oocyte yield and oocyte quality grade by $\mathrm{CL}$ presence.

\begin{tabular}{|c|c|c|}
\hline Item measured & \multicolumn{2}{|c|}{ Corpus luteum status } \\
\hline Total Follicle Aspirated & Absent & Present \\
\hline Mean aspirated follicle (Per session) & 331 & 325 \\
\hline Mean follicle by size / Per session & $10.39 \pm .7$ & $9.44 \pm .64$ \\
\hline Small (3-4mm) & & \\
\hline Medium (5mm-9mm) & $4.51 \pm .43$ & $3.41 \pm .23$ \\
\hline Large (>9mm) & $3.56 \pm .29$ & $3.59 \pm .31$ \\
\hline Total oocytes recovered & $2.89 \pm .22$ & $2.53 \pm .24$ \\
\hline Recovery rate & 218 & 211 \\
\hline Mean oocyte by Coc quality grade & $65.86 \%$ & $64.92 \%$ \\
\hline Grade 1 oocyte & & \\
\hline Grade 2 oocyte & $2.35 \pm .21$ & $2.54 \pm .21$ \\
\hline Grade 3 oocyte & $2.89 \pm .33$ & $3.34 \pm .33$ \\
\hline
\end{tabular}

Table 3: Oocyte maturation and cleavage by $\mathrm{CL}$ presence or absence.

\begin{tabular}{|c|c|c|}
\hline Item measured & \multicolumn{2}{|c|}{ Corpus luteum status } \\
\hline & Absent & Present \\
\hline Total oocytes cultured* & 166 & 154 \\
\hline Mean No of cultured oocyte/session & $4.17 \pm .59$ & $3.29 \pm .46$ \\
\hline Total No of oocytes matured & 89 & 74 \\
\hline Mean No of oocytes matured/sessiont & $2.8 \pm .54$ & $2.13 \pm .29$ \\
\hline Oocyte maturation rate (\%) & 53.61 & 48.05 \\
\hline Cleavage rate (\%) & 32.53 & 30 \\
\hline Mean cleaved embryos/session & $2.16 \pm .60$ & $1.5 \pm .28$ \\
\hline
\end{tabular}

* Grade 1 and Grade 2 oocytes were cultured, $\mathbf{t}$ oocytes with first polar body and expanded cumulus cells

Table 4: Changes in the mean follicles of different category by FSH dose, and by coasting time.

\begin{tabular}{|c|c|c|c|c|}
\hline FSH dose & $\begin{array}{c}\text { FSH Protocol \& } \\
\text { OPU time }\end{array}$ & Mean $( \pm S E)$ a & irated follicles by & ollicle catego \\
\hline \multirow{4}{*}{350 IU FSH } & & $\begin{array}{l}\text { Small Follicle } \\
\quad(3-4 \mathrm{~mm})\end{array}$ & $\begin{array}{l}\text { Medium Follicle } \\
\quad(5-9 \mathrm{~mm})\end{array}$ & $\begin{array}{l}\text { Large Follicle } \\
\qquad(>9 \mathrm{~mm})\end{array}$ \\
\hline & mFSH/48h OPU & $4.30 \pm 0.57^{\mathrm{a}}$ & $7.36 \pm 0.57^{a}$ & $8.28 \pm 0.96^{\mathrm{a}}$ \\
\hline & sFSH/48h OPU & $3.67 \pm 0.42^{b}$ & $3.55 \pm 0.28^{b}$ & $2.88 \pm 0.22^{b}$ \\
\hline & $\mathrm{mFSH} / 72 \mathrm{~h}$ OPU & $3.72 \pm .20^{\mathrm{b}}$ & $5.94 \pm 0.43^{c}$ & $6.81 \pm 0.55^{c}$ \\
\hline 175 IU FSH & mFSH/48h OPU & $3.30 \pm .17^{b}$ & $5.02 \pm .16^{c}$ & $5.74 \pm .22^{c}$ \\
\hline No FSH & Control* & $4.51 \pm .43^{a}$ & $3.56 \pm .29^{b}$ & $2.89 \pm .22^{\mathrm{b}}$ \\
\hline
\end{tabular}

$a, b, c$ Within the column values with different scripts (letters) differs significantly $(\mathrm{P}<0.05)$, * OPU without FSH and without corpus luteum on ovaries was considered as a control

The details of oocyte quality grade and oocyte recovery rate by FSH protocols are indicated in Table 5 . The mean grade one and grade two oocytes were significantly higher $(\mathrm{P}<0.05)$ in the $350 I U$ FSH divided dose than 350 IU FSH given as a single dose. Similarly, the 350 IU FSH divided dose significantly increased mean grade one and grade two oocytes than the 175IU divided FSH dose. The $48 \mathrm{~h}$ coasting period significantly increased $(\mathrm{P}<0.05)$ the mean grade one and grade two oocytes than the $72 \mathrm{~h}$ costing periods.

The details of mean oocytes cultured, oocytes matured and 
cleaved are indicated in Table 6. Maturation rate and cleavage rate were significantly higher when the 350 IU FSH priming was given in divided doses regardless of the coasting time Similarly, the 350IU divided FSH dose resulted in significantly higher $(\mathrm{P}<0.05)$ oocytes matured both at costing period of $48 \mathrm{~h}$ (3.96 \pm .49$)$ and $72 \mathrm{~h}(3.61 \pm .49)$ than the 300IU single FSH dose and 175IU divided FSH dose. Oocyte cleavage rate and the mean oocytes cleaved were significantly higher $(\mathrm{P}<0.05)$ in the $350 \mathrm{IU}$ divided FSH dose than other protocols.

\section{Discussion}

In present study, mean aspirated follicles, recovered oocytes, COC quality grade and mean numbers of matured and cleaved oocytes were not affected by CL presence on the ovary. In previous work Pirestani, et al. [14] indicated that ovaries with CL yield higher average oocyte collected per ovary than ovaries without CL. Findings on the effect of CL presence or absence on aspirated follicles, recovered oocytes and COC quality were inconsistent. The inconsistency among different studies may be due to breed of cattle used, cows' body condition score, and environmental temperature in which cows kept [15-19]. Penitente, et al. [20] reported that follicular fluid biochemical metabolites concentration were related to the presence or absence of corpus luteum and this may also be the reason for differences in mean numbers of matured and cleaved oocytes from study to study.

Similar to the present findings, Lonergan, et al. [21] reported that administration of six injections of pFSH beginning 3 days prior to slaughter resulted in a significant increase in the proportion of follicles $>6 \mathrm{~mm}$ in diameter compared to that in non treated controls. Some other previous works (Goodhand, et al. [22]; De Roover, et al. [23]; Vieira, et al. [24] and Egashira, et al. [25] reported that multiple FSH administration prior to OPU significantly increases the number of follicles aspirated, the number of oocytes recovered and $\mathrm{COC}$ quality than single dose FSH and than no FSH treated control. However, Bols et al. [26] and Techakumphu, et al. [27] indicated that FSH stimulation facilitates follicle aspiration but it would not improve or even decrease oocyte recovery rate. Vieira, et al. [13] indicated that oocyte recovery rate was significantly lower from FSH treated donors than non-treated. The inconsistency on effect of FSH stimulation on follicles aspirated and oocytes recovered may be due to animal related factors (Age, physiology and estrus cycle stage at OPU) or it may be due to animal management especially of feeding regimen (nutrient), and /or climate in which animals reared. The frequency of OPU made within a week may also contribute to the inconsistency of result in different studies. The works of Lopes, et al. [28] and Li, et al. [29] indicated viable oocytes and transferable embryos are affected by OPU frequency.

In agreement to present finding, Seneda et al. [30] reported that efficiency of oocyte recovery was greater when follicles were aspirated at $48 \mathrm{~h}$ ( 2 days) of FSH (at small follicles) than when follicles were aspirated on Day 5 (at large follicles) although the average number of oocytes obtained per cow for each group did not differ. The work of Blondin et al. [7] indicated that $48 \mathrm{~h}$ coasting period gives significantly more $5 \mathrm{~mm}$ to $10 \mathrm{~mm}$ follicles than $33 \mathrm{~h}$ coasting period.

In present study, divided FSH administration prior to OPU significantly $(\mathrm{P}>0.05)$ increased the mean number of matured and cleaved oocytes and this was in contrast with work of Vieira, et al. [24]. In previous works, effect of FSH on oocyte cleavage rate differs from study to study and remains inconsistent $[25,28]$. The difference in this finding was probably due to the difference in the number of oocytes matured as divided FSH dose increased oocyte recovery rate and oocytes matured and cultured. The source for the difference among these studies might also be due to cattle breed used and/or the physiologic status of the cows used. It could be concluded that in Boran cows, follicular ablation and treatment of cows with FSH prior to aspiration improves follicular population and oocyte recovery rate during ovum pickup. The 350IU FSH given in divided doses and OPU after $48 \mathrm{~h}$ coasting period was effective for higher oocyte recovery rate than the 175IU FSH given in divided doses. The175IU FSH given in divided doses after $48 \mathrm{~h}$ coasting period was effective for higher oocyte recovery rate than with no FSH treatment.

Table 5: The mean oocyte grade by FSH protocol and by coasting time.

\begin{tabular}{|c|c|c|c|c|c|c|c|}
\hline FSH Dose & Protocol & G1 oocyte & G2oocyte & G3oocyte & Total oocyte & $\begin{array}{c}\text { Total } \\
\text { Follicle }\end{array}$ & $\begin{array}{c}\text { Recovery } \\
\text { rate }\end{array}$ \\
\hline \multirow{3}{*}{$\begin{array}{c}350 \\
\text { IU }\end{array}$} & $\mathrm{mFSH} / 48 \mathrm{~h}$ OPU & $4.19 \pm 0.24^{\mathrm{a}}$ & $4.32 \pm .27^{a}$ & $1.32 \pm 022^{a}$ & $559^{a}$ & $930^{a}$ & $63.76 \%$ \\
\hline & sFSH/48h OPU & $2.95 \pm .24^{b}$ & $2.34 \pm .38^{b}$ & $0.31 \pm .28^{\mathrm{b}}$ & $278^{b}$ & $510^{\mathrm{b}}$ & $54.5 \%$ \\
\hline & $\mathrm{mFSH} / 72 \mathrm{~h}$ OPU & $3.17 \pm .31^{c}$ & $3.29 \pm .31^{c}$ & $1.24 \pm .13^{\mathrm{a}}$ & $564^{\mathrm{a}}$ & $921^{\mathrm{a}}$ & $61.24 \%$ \\
\hline $175 \mathrm{IU}$ & $\mathrm{mFSH} / 48 \mathrm{~h}$ OPU & $3.06 \pm .32^{c}$ & $3.32 \pm .18^{c}$ & $0.99 \pm .43^{b}$ & $454^{c}$ & $741^{c}$ & $61.28 \%$ \\
\hline NoFSH & Control & $2.35 \pm .21^{\mathrm{b}}$ & $2.89 \pm .33^{b}$ & $1.72 \pm .16^{\mathrm{a}}$ & $218^{\mathrm{ab}}$ & $331^{a b}$ & $65.86 \%$ \\
\hline
\end{tabular}

a, b, c Within columns cells different scripts (letters) differ significantly $(P<0.05)$

Table 6: The maturation and cleavage rate during different FSH priming and coasting period

\section{FSH dose Protocol}

\begin{tabular}{c|c}
\hline \multirow{3}{*}{300 IU FSH } & \multicolumn{2}{|c}{ Proth/48h OPU } \\
\cline { 2 - 2 } & $\mathrm{mFSH} / 48 \mathrm{~h}$ OPU \\
\cline { 2 - 2 } $175 \mathrm{IU} F S H$ & $\mathrm{mFSH} / 72 \mathrm{~h}$ OPU \\
\hline No FSH & $\mathrm{mFSH} / 48 \mathrm{~h}$ OPU \\
\hline
\end{tabular}

\begin{tabular}{|c|}
\hline $\begin{array}{c}\text { Total oocyte } \\
\text { Cultured }\end{array}$ \\
\hline $365^{\mathrm{a}}$ \\
\hline $301^{\mathrm{c}}$ \\
\hline $339^{\mathrm{b}}$ \\
\hline $303^{\mathrm{c}}$ \\
\hline 166 \\
\hline
\end{tabular}

Mean Oocytes matured and ooctes cleaved

Maturation
Rate $(\%)$
$70.41^{\mathrm{a}}$
$55.48^{\mathrm{c}}$
$67.85^{\mathrm{a}}$
$62.4^{\mathrm{b}}$
$53.61^{\mathrm{c}}$

\begin{tabular}{|c|c|}
$\begin{array}{c}\text { Cleavage } \\
\text { Rate }(\%)\end{array}$ & $\begin{array}{c}\text { Mean oocyte } \\
\text { Cultured/OPU* }\end{array}$ \\
\hline $47.5^{\mathrm{a}}$ & $5.89 \pm .55^{\mathrm{a}}$ \\
\hline $30.1^{\mathrm{c}}$ & $3.41 \pm .66^{\mathrm{b}}$ \\
\hline $43.48^{\mathrm{b}}$ & $5.06 \pm .56^{\mathrm{a}}$ \\
\hline $42.33^{\mathrm{b}}$ & $4.64 \pm 1.11^{\mathrm{b}}$ \\
\hline $32.53^{\mathrm{c}}$ & $4.17 \pm .59^{\mathrm{b}}$ \\
\hline
\end{tabular}

\begin{tabular}{|c|c|}
\hline $\begin{array}{c}\text { Mean oocyte } \\
\text { matured }\end{array}$ & $\begin{array}{c}\text { Mean oocyte } \\
\text { cleaved/OPU }\end{array}$ \\
\hline $3.96 \pm .49^{\mathrm{a}}$ & $2.78 \pm .32^{\mathrm{a}}$ \\
\hline $2.90 \pm .56^{\mathrm{b}}$ & $1.77 \pm .32^{\mathrm{b}}$ \\
\hline $3.61 \pm .49^{\mathrm{a}}$ & $2.17 \pm .37^{\mathrm{a}}$ \\
\hline $2.82 \pm .35^{\mathrm{b}}$ & $1.78 \pm .23^{\mathrm{b}}$ \\
\hline $2.8 \pm .54^{\mathrm{b}}$ & $2.16 \pm .60^{\mathrm{a}}$ \\
\hline
\end{tabular}




\section{Acknowledgments}

The authors would like to thank Mr Abiy Shimelis, Mr Seid Ali, Mr Getachew Deresu and who helped us in oocyte collection.

\section{Ethics approval}

Certificate was received (certificate No VM/ ERC/25/01/12/2020) from animal research ethics review committee of College of Veterinary Medicine and Agriculture and all procedures was in comply with ERC procedure.

\section{Availability of data and material}

The corresponding author would give data on a reasonable request

\section{Authors' contributions}

Tilaye Demissie has generated research idea (conceptualization), developed proposal and prepared first draft manuscript. Tilaye Demissie has conducted research and generated data. Tefera Yilma, Tamrat Degefa, Gemechu Wirtuand and Alemayehu Lemma have approved the study methodology, edited the first draft and the final manuscript. All authors have read and approved the manuscript for publication.

\section{References}

Azage T, Eshete D, Dirk H, Worku T (2009) Matching Genotype with the Environment Using Indigenous Cattle Breed: Introduction of Borana Cattle from Southern Ethiopia into the Lowlands of North-Western Ethiopia. A paper presented at the FAO/IAEA Symposium on Sustainable Improvement of Animal Production and Health,Vienna, Austria. Link: https://bit.ly/3AWDVrL

2. Mekonnen H, Malmfors B, Philipsson J (2010) BORAN: Indigenous African cattle with potential.

3. Reis PO, Martins CM, Gimenes LU, Sales JNS, Baruselli PS (2010) Effect of synchronization of the follicular wave emergence on OUP-IVP of Nelore (Bos indicus) and Brangus (Bos taurus X Bos indicus). Acta Sci Vet 38: 385.

4. Rodroguez P, Tribulo A, Ramos M, Ongaratto FL, Bo GA (2010) Comparoson of oocyte recovery rates and morphology obtained by OPU after different hormonal treatments in cattle. XXVI world Buitric Congress, Santiago, Chile.

5. Meintijes M, Bellow MS, Broussard JR, Paul JB, Godke RA (1995) Transvaginal aspiration of oocytes from hormone-treated pregnant beef cattle for in vitro fertilization. J anim Sci 73: 967-74. Link: https://bit.ly/3E2LDCt

6. Chasombat J, Nagai T, Pampai R, Vongpralub T (2013) Ovarian Follicula Dynamics, Ovarian Follicular Growth, Oocyte Yield, In vitro Embryo Production and Repeated Oocyte Pickup in Thai Native Heifers Undergoing Superstimulation. Asian-Australas J Anim Sci. 26: 488-500. Link: https://bit.ly/3GabVVp

7. Blondin $P$, Bousquet $D$, Twagiramungu $H$, Barnes $F$, Siradr MA (2002) Manipulation of Follicular Development to Produce Developmentally Competent Bovine Oocytes. Biol Reprod 66: 38-43. Link: https://bit.ly/3E2EKBi

8. Chaubal SA, Molina JA, Ohrichs CL, Ferre LB, Faber DC, et al. (2006) Comparison of different transvaginal ovum pick up protocols to optimize oocyte retrieval and embryo production over a 10 week period in cows. Theriogenology 65 1631-1648. Link: https://bit.ly/3B5TOMm

9. Sirad MA, Richrd F, Blondin P, Robert C (2006) Contribution of oocyte to embryo quality. Theriogenology 66: 126-136. Link: https://bit.ly/3E326GU

10. Nivet AL, Bunel A, Labrecque R, Belanger J, Vigneault C, et al. (2012) FSH withdrawal improves developmental competence of oocytes in the bovine model. Reproduction 143: 165-171. Link: https://bit.ly/2ZdMC41

11. Walters AH, Bailey TL, Pearsom RE, Gwazdauskas FC (2002) PariyRelated Changes in Bovine Follicle and Oocyte Populations, oocyte Quality and Hormone to 90 Days Postpartum. J Dairy Sci 85: 824-832. Link: https://bit.ly/3Chj04d

12. Alves BG, Alves KA, Lúcio AC, Martins MC, Silva TH, et al. (2014) Ovarian activity and oocyte quality associated with the biochemical profile of serum and follicular fluid from Girolando dairy cows post partum. Anim Reprod Sci 146: 117-125. Link: https://bit.ly/3B3DZpF

13. Vieira LM, Rodrigues CA, Netto AC, Guerreiro BM, Silveira CRA, et al. (2014) Superstimulation prior to the ovum pick-up to improve in vitro embryo production in lactating and non-lactating Holstein cows. Theriogenology 82 318-324. Link: https://bit.ly/3poq37

14. Pirestani A, Hosseini SM, Hajian M, Forouzanfar M, Moulavi F, et al. (2011) Effcet of ovarian cyclic status on in vitro embryo production in cattle. Int $J$ Fertil Steril 4:172. Link: https://bit.ly/3aVGUpx

15. Snijders S, Dillon P, O'Callaghan D, Boland M (2000) Effect of genetic merit, milkyield, body condition and lactation number on invitro oocyte development in dairy cows. Theriogenology 53: 981-989. Link: https://bit.ly/3vvtXMS

16. Wolfenson D, Roth Z, Meidan R (2000) Impaired reproduction in heat stressed cattle: basic and applied aspects. Anim Reprod Sci 60: 535-547. Link: https://bit.ly/3niYnON

17. Neglia G, Gasparini B, di Brienza VC, di Palo R, Campanile G, et al. (2033) Bovine and Buffalo in vitro embryo production using oocytes derived from abattoir ovaries or collected by transvaginal follicle aspiration. THeriogenology 59 1123-1130. Link: https://bit.ly/3aVBLOz

18. Sugulle AH, Dochi O, Koyama H (2008) Developmental competence of bovine oocytes selected by by brilliantcresyl blue staining effect of the presence of corpus luteum on embryo development. J Mamm OvaRes 25: 50-55. Link: https://bit.ly/30HI9lh

19. Shabankareh HK, Kor NM, Hajarian H (2013) The influence of the corpus luteum on metabolic composition of follicular fluid from different sized follicles and their relationship to serum concentration in dairy cows. Anim Reprod Sci 140: 109-114. Link: https://bit.ly/3poqw9y

20. Penitente F, Jimenez CR, Zolini AM, Carrascal E, Azevedo JL, et al. (2015) Influence of corpus luteum and ovarian volume on the number and quality of bovine oocytes. J Anim Sci 86: 148-152. Link: https://bit.ly/30BrZ1V

21. Lonergan P, Monaghan P, Rizos D, Boland MP, Gordon I (1994) Effect of Follicle Size on Bovine Oocyte Quality and Developmental Competence Following Maturation, Fertilization and Cuture in vitro. Mol Reprod Dev 37: 48-53. Link: https://bit.ly/30DOKUG

22. Goodhand KL, Staines ME, Hutchinson JSM, Broadbent PJ (2000) In vivo oocyte recovery and in vitro embryoproduction from bovine oocyte donors treated withprogestagen, oestradiol and FSH. Anim Reprod Sci 63: 145-158. Link: https://bit.ly/3nwruOL

23. De Roover R, Bols PEJ, Genicot G, Hanzen Ch (2005) Characterisation of low, medium and high responders following FSH stimulation prior to ultrasoundguided transvaginaloocyte retrieval in cows. Theriogenology 63: 1902-1913. Link: https://bit.ly/3jnj2AO

24. Vieira LM, Rodrigues CA, Netto AC, Guerreiro BM, Silveira CRA, et al. (2016) Efficacy of a single intramuscular injection of porcine FSH in hyaluronan prior to ovum pick-up in Holstein cattle. Theriogenology 85: 877-886. Link: https://bit.ly/3jlhvu0

25. Egashira J, Ihara Y, Khatun H, Wada Y, Konno T, et al. (2019) Efficient in vitro embryo production using in vivo-matured oocytes from superstimulated Japanese Black cows. J Reprod Dev 65: 184-190. Link: https://bit.ly/2Z8yQjh

Citation: Demissie T, Yilma T, Degefa T, Wirtu G, Lemma A (2021) Effect of follicular ablation and gonadotropin priming on the recovery and quality of oocytes in Boran cows. Int J Vet Sci Res 7(2): 138-143. DOI: https://dx.doi.org/10.17352/ijvsr.000093 
26. Bols PEJ, Ysebaert MT, Lein A, Coryn M, van Soom A, et al. ( 1998) Effects of long-term treatment with bovine somatotropin on follicular dynamics and subsequent oocyte and blastocyst yield in an OPU-IVF program. Theriogenology 49: 983-995. Link: https://bit.ly/3aXQiJr

27. Techakumphu M, Promdireg A, Na-Chiengmai A, Phutikanit N (2004) Repeated oocyte pick up in prepubertal swamp buffalo (Bubalus bubalis) calves after FSH superstimulation. Theriogenology 61: 1705-1711. Link: https://bit.ly/3G4f09k

28. Lopes AS, Martinussen T, Greve T, Callesen H (2006) Effect of days postpartum, breed and ovum pick-up scheme on bovine oocyte recovery and embryo development. Reprod Domest Anim 41: 196-203. Link: https://bit.ly/3aWMSXc

29. Li F, Chen X, Pi W, Liu C, Shi Z (2007) Collection of oocytes through transvaginal ovum pick-up for in vitro embryo production in Nanyang Yellow cattle. Reprod Domest Anim 42: 666-670. Link: https://bit.ly/3jj73TW

30. Seneda MM, Esper CR, Andrade ER, Binelli M, Max MC, et al. (2005) Relationship between follicle size after FSH treatment and efficiency of oocyte recovery. Anim Reprod 2: 178-182. Link: https://bit.ly/3E1kfVl
Discover a bigger Impact and Visibility of your article publication with Peertechz Publications

\section{Highlights}

* Signatory publisher of ORCID

* Signatory Publisher of DORA (San Francisco Declaration on Research Assessment)

* Articles archived in worlds' renowned service providers such as Portico, CNKI, AGRIS, TDNet, Base (Bielefeld University Library), CrossRef, Scilit, J-Gate etc.

- Journals indexed in ICMJE, SHERPA/ROMEO, Google Scholar etc.

* OAI-PMH (Open Archives Initiative Protocol for Metadata Harvesting)

* Dedicated Editorial Board for every journal

* Accurate and rapid peer-review process

* Increased citations of published articles through promotions

* Reduced timeline for article publication

Submit your articles and experience a new surge in publication services (https://www.peertechz.com/submission).

Peertechz journals wishes everlasting success in your every endeavours. 